\section{Siniša Subotić ${ }^{1}$}

NVO „Persona”, Banjaluka; CEON, Beograd

\title{
INKLUZIJA, MORALNOST I REALNOST: ODGOVORI NA TEŠKA PITANJA²
}

Inkluzija u obrazovanju ubrzano postaje dominantna paradigma obrazovanja djece s disabilitetima, uprkos uglavnom nedovoljno uvjerljivim nalazima u vezi sa formalnim ishodima njene implementacije. U ovom preglednom radu data je sistematična logičko-filozofska dekonstrukcija ključnih ideja inkluzije (poput postmodernističkog odbacivanja naučnog metoda i negiranja egzistencije disabiliteta), uz ukazivanje na njihove očigledne logičke kontradikcije. Posebna pažnja poklonjena je formalnom demantu postulirane apriorne moralne ispravnosti inkluzije. Polazeći od moralne teorije univerzalno preferabilnog ponašanja, demonstrirano je da je inkluzija, s obzirom na to da je utemeljena na kompulzivnoj obrazovnoj paradigmi i uzrasnoj segregaciji, apriorno podjednako moralno neopravdana kao i specijalno obrazovanje. lako ispravno zastupa poziciju nemoralnosti bilo kakve segregacije, inkluzija je, dakle, logički i sama oblik segregacije. Ovo ima važne praktične implikacije jer pokazuje da je sama inkluzija uzročnik mnogih problema koji se pogrešno pripisuju njenoj neadekvatnoj implementaciji, te da optimalna implementacija zapravo nije moguća. Ovo dijelom objašnjava i inherentnu trivijalnost i praktičnu neupotrebljivost mnogih istraživanja koja se bave inkluzijom, poput ispitivanja stavova. Dati su i praktični primjeri toga kako je moguće prevazići problem trivijalnosti i odgovoriti na empirijska pitanja od neposrednog značaja. Pri tome, ukazano je da su ovakva pitanja, iako važna, prelaznog karaktera, jer je zaključak koji se nameće taj da problem obrazovanja djece sa ili bez disabiliteta ne može biti riješen unutar aktuelne obrazovne paradigme, ali da smo u međuvremenu primorani da se bavimo „minimizacijom štete“.

Ključne riječi: inkluzija, moralnost, univerzalno preferabilno ponašanje (UPB), kompulzivno obrazovanje, pregled istraživanja

${ }^{1}$ Adresa autora: sinisasub@
gmail.com

Primljeno: 29. 05. 2014. Primljena korekcija:

28. 07. 2014.

Prihvaćeno za štampu:

29. 07. 2014.
${ }^{2}$ Ovaj pregled zasniva se u određenoj mjeri na filozofsko-logičkoj argumentaciji i empirijskim nalazima prezentovanim u okviru moje doktorske disertacije (Subotić, 2014) i njenim formalnim pilot-istraživanjima (Subotić, 2010, 2011). Iako ovaj članak u kondenzovanoj formi prikazuje neke od glavnih filozofskih argumenata i istraživačkih nalaza pomenutih istraživanja (i nadopunjuje ih velikim brojem novih argumenata, pojašnjenja i sinteza), zainteresovane čitaoce pozivam da konsultuju puni tekst disertacije (dostupan sa http://goo.gl/yQoNdE), u cilju dobijanja potpunijeg uvida u sva relevantna pitanja. 
Inkluzija u obrazovanju aktuelno je i kontroverzno pitanje. Pristalice je nazivaju „gotovo savršenim obrazovnim sistemom“ (Wang, 2009, p. 155), uprkos neuvjerljivim empirijskim potvrdama (Lindsay, 2007). U ovom konceptualnopreglednom radu, kritički ću razmotriti temeljne ideje inkluzije, poput negiranja empirijskih nalaza, oslanjanja na postmodernizam i odbacivanja disabiliteta. Posebnu pažnju pokloniću ključnom pitanju moralnosti inkluzije. Nakon što demonstriram višestruke logičke kontradikcije u ovim idejama, pozabaviću se praktičnim naučno-istraživačkim pitanjima koja iz tog proizlaze. Stoga, cilj ovog rada je dvojak. Prvo, da ukaže na logičko-filozofske nedostatke u inkluzivnoj retorici. I drugo, da ilustruje kako sprovoditi korisnija istraživanja u svjetlu tih nedostataka.

\section{Konceptualna razmatranja}

\section{Osnovne ideje inkluzije}

Inkluziju u obrazovanju moguće je definisati kao praksu aktivnog uključivanja u „redovni“ nastavni proces djece sa senzo-motoričkim ili intelektualnim disabilitetima, tj. djece koja bi „tradicionalno“ pohađala specijalne škole (Subotić, 2010, 2014). Inkluzija pretenduje na to da promijeni opšte obrazovanje za sve učenike, sa ili bez disabiliteta (Kavale \& Forness, 2000), a pokret je u ekspanziji, uključujući i zemlje bivše Jugoslavije (npr. Jablan, Jolić-Marjanović, \& Grbović, 2011; Macura-Milovanović i Vujisić-Živković, 2011; Sindik, 2013; Subotić, 2010, 2014; Žiljak, 2013).

Postoje dvije glavne struje inkluzije (vidjeti: Fuchs \& Fuchs, 2000; Subotić, 2014) - kontinuum uključivanja („parcijalna inkluzija“) i (pot)puna inkluzija. Kontinuum uključivanja podrazumijeva balansiranjeizmeđunastavnihinstrukcija pruženih u okviru redovne učionice i izdvojenih specijalnih instrukcija (u okviru specijalizovanih ustanova ili same škole) i dopušta i potpuno uključivanje, ali i potpuno izdvajanje učenika, što se procjenjuje na individualnoj bazi. Zagovornici pune inkluzije propagiraju nužno uključivanje svih učenika u redovne učionice i insistiraju na tome da su učenici sa disabilitetima prirodni članovi škola i uzrasno prikladnih redovnih razreda koje pohađaju (Neary \& Halvorsen, 1995). Kontinuum uključivanja posmatraju samo kao prelazno rješenje, a konačni cilj je puna inkluzija (Lipsky \& Gartner, 1991).

\section{Empirijske potvrde inkluzije}

Iako ponekad eksplicitno obećava maksimizaciju obrazovnih benefita (Brice \& Miller, 2000), sinteze nalaza ukazuju na generalno neuvjerljivu efikasnost inkluzije. Tako Begeny i Martens opisuju slučaj Italije, koja iako važi 
za „odličan primjer toga kako ostvariti široku implementaciju inkluzije“ (Begeny \& Martens, 2007, p. 80), „čini se da zapravo postoji vrlo malo činjenica u vezi sa direktnim ishodima i koristima od takvih napora" (p. 89). I drugi pregledi uglavnom izvještavaju o mješovitim socio-akademskim ishodima inkluzije za učenike s disabilitetima (npr. Salend \& Duhaney, 1999), uz opaske da uprkos ostvarenoj ideološkoj i političkoj podršci, empirijski ishodi inkluzije nisu toliko uvjerljivi (Kavale \& Forness, 2000). Sličan zaključak navodi i Lindsey (2007) u najobuhvatnijem novijem sistematičnom pregledu literature o inkluziji, pišući da: „Činjenice iz ovog pregleda ne pružaju jasnu podršku postojanju pozitivnih efekata inkluzije. Nedovoljno je nalaza iz prikladnih studija, a kada ih i ima, balans je samo marginalno pozitivan“ (p. 2). Lindsey (2007) dodaje i da: „[...] izostaje stabilna istraživačka osnova inkluzivnog obrazovanja koja bi potvrdila da li je ovo preferabilan pristup u pogledu ishoda, kao i kako bi inkluziju trebalo implementirati“ (p. 16).

\section{Negiranje empirije i oslanjanje na postmodernizam}

Jedan od uobičajenih odgovora pristalica inkluzije (skr. inkluzionista) na nepovoljne empirijske nalaze jeste naprosto negiranje naučnog metoda, izvedeno iz tzv. postmodernističke misli, koju u nauci karakteriše odbacivanje racionalističke tradicije i empiricizma, uz kognitivni i kulturalni relativizam koji nauku tretira kao mit, naraciju ili socijalni konstrukt (Kavale \& Forness, 2000; Sokal, 2006; Subotić, 2014; Uduigwomen, 2005). Prema postmodernizmu, istina ne korespondira sa realnošću, odnosno ne postoji objektivna/univerzalna istina i umjesto (uzaludne) potrage za njom, treba se fokusirati na subjektivnu interpretaciju, koja uvijek zavisi od nekakvog socio-kulturalnog konteksta (Uduigwomen, 2005). Konceptualno, inkluzija je postmodernistička ideja (Kavale \& Forness, 2000; Subotić, 2014) i inkluzionisti sada već uobičajeno zastupaju poziciju da su obrazovni problemi u nekom smislu specifični i da je „otvoreno za debatu“ (Thomas \& Glenny, 2002, p. 348) da li je empirijska epistemologija, kao „samo jedan oblik razuma“ (p. 346) prikladna za ispitivanje većine ovakvih pitanja (ali bez obrazloženja zašto je to navodno tako).

Postoje najmanje dva problema u vezi sa postmodernističkom pozicijom inkluzije. Prije svega, sama polazna premisa postmodernizma vodi u očiglednu logičku kontradikciju. Naime, tvrdnja da ne postoji objektivna/univerzalna istina i sama podrazumijeva tvrdnju o univerzalnoj istini, koja se istovremeno negira. Dakle, ako je tvrdnja istinita, onda ne može biti istinita. Napomena: Istina je ovdje shvaćena unutar lingvističkog konteksta, a ne u nekakvom eksternom smislu (vidjeti: Subotić, 2014).

Drugi problem je taj da postmodernizam nužno vodi u subjektivizaciju i relativizam (Uduigwomen, 2005). Ovim i sve inkluzionističke kritike naučnog 
metoda takođe potpadaju pod kategoriju subjektivnih tvrdnji, koje onda i same ne mogu biti ništa manje ili više ispravne od bilo kojih drugih tvrdnji, uključujući i njihove negacije. Ovo je logički nespojivo s pretenzijom inkluzije da zastupa jednu jedinu ispravnu poziciju.

\section{Subjektivnost/socijalna konstrukcija i negacija disabiliteta}

Inkluzionisti glasno kritikuju "tradicionalno" shvatanje disabiliteta. Ove kritike variraju od isticanja neumjesnosti imenovanja i kategorizovanja (Brantlinger, 1997; Brice \& Miller, 2000), preko ukazivanja na mogućnosti zloupotrebe (Brantlinger, 1997; Mamlin \& Harris, 1998), do potpunog negiranja svih disabiliteta, svojstvenog punoj inkluziji. Na primjer: „[...] tradicionalisti pišu kao da su disabiliteti urođeni, a ne socijalno konstruisani [...]" (Brantlinger, 1997, p. 440). Odnosno: „[...] disabiliteti su socijalni konstrukti koji svoju 'egzistenciju' duguju vrijednosno pristrasnim sudovima o određenim ljudskim atributima" (Gallagher, 2001, p. 643). Kavale i Mostert (Kavale \& Mostert, 2003, p. 193) odgovaraju na ovo tvrdnjom da ako disabiliteti egzistiraju isključivo zahvaljujući socijalnoj konstrukciji, onda je moguće ukloniti ih socijalnom dekonstrukcijom. Odnosno, „socijalne sile bi trebale da mogu vratiti [osobama s disabilitetima] prosječnu ili iznadprosječnu inteligenciju, $20 / 20$ vid i punu i normalnu kontrolu nad udovima".

Ovo ne eliminiše mogućnost da neki disabiliteti jesu socijalni konstrukti, ali čak i u tom slučaju, socijalni konstrukti ne moraju nužno biti subjektivni i bez funkcionalne vrijednosti. Primjer bi bio jezik. Iako je takođe socijalni konstrukt, sama činjenica da neko čita ovu rečenicu i razumije ideju koju sam njome izrazio, potvrđuje makar minimalnu funkcionalnu objektivnost i vrijednost jezika (vidjeti: Molyneux, 2007). Ovo automatski demantuje "tvrdo shvatanje“ o svim konstruktima kao nužno subjektivnim. Takođe, ako i prihvatimo pretpostavku o socijalnoj konstruisanosti disabiliteta, bez dodatnog specifikovanja osnove po kojoj su disabiliteti manje vrijedni u svjetlu svog „,socijalno-konstruisanog statusa“ u odnosu na druge socijalne konstrukte (pod šta potpada i sama inkluzija), ispada da su i željene, tj. inkluzija i neželjene manifestacije, tj. disabiliteti, paradoksalno definisane preko identične karakteristike - socijalne konstrukcije, što je logička kontradikcija.

\section{Inkluzija kao moralni imperativ}

Najčešće navođen razlog zašto inkluziju treba primjenjivati (bez obzira na nalaze) tiče se njene postulirane moralne ispravnosti (Brantlinger, 1997; Gallagher, 2001; Thomas \& Glenny, 2002). Odnosno: „[p]itanje inkluzije je, na kraju, neizbježno moralno“ (Gallagher, 2001, p. 650), pri čemu se njeno 
procjenjivanje „odvija na području vrijednosti i načela, a ne rezultata“ (Žiljak, 2013, str. 280). Stoga, „bez obzira na podatke koji se odnose na ishode inkluzije, nju treba primjenjivati jer je moralno korektna“ (Begeny \& Martens, 2007, p. 90) i „[...] moralni je imperativ koji niti zahtijeva, niti može da čeka na empirijsku potvrdu“ (Cook, Semmel, \& Gerber, 1999, p. 199). Takođe, nalazi koji ne idu u prilog inkluziji mogu biti odbačeni pošto ne mogu biti korišteni kao osnova za ono kako bi (prema idejama inkluzije) trebalo da bude (Lindsey, 2007), što se kosi sa bazičnim naučnim principom opovrgljivosti (Popper, 2005).

Međutim, inkluzionisti ne argumentuju zašto je inkluzija moralni imperativ. Objašnjenja se svode na apele za „uvažavanje moralnih i političkih prava učenika u inkluzivnom obrazovanju“ (Wang, 2009, p. 155), u kontekstu „[...] šireg pokreta ljudskih prava, koji postulira da su svi oblici segregacije moralno neispravni“ (Avramidis, Bayliss, \& Burden, 2010, p. 192). Kavale i Forness navode da je: „Ignorišući rezultate istraživanja, inkluziona debata uzdigla diskusiju na nivo ideologije, na kome je teško razriješiti konflikte različitih vizija“ (Kavale \& Forness, 2000, p. 279). U skladu s ovim, inkluzionisti više pažnje poklanjaju karakterizaciji konvencionalnog specijalnog obrazovanja kao „zle imperije“ (Kauffman, 1999, p. 245), nego što argumentuju opravdanost sopstvene pozicije.

Dekonstrukcija postulirane apriorne moralnosti inkluzije. Inkluzija svoju premisu temelji na tzv. argumentu (apriorne) moralnosti (Molyneux, 2005, 2007), prema kom moralnost egzistira kao apriorna kategorija i ne može biti procijenjena iz ishoda akcije (tzv. ,jeste-treba“ problem; vidjeti: Cohon, 2010; Subotić, 2014). Stoga ću demant moralnosti inkluzije izvršiti na osnovu teorije univerzalno preferabilnog ponašanja (engl. universally preferable behaviour, skr. UPB, Molyneux, 2007), koja i sama počiva na istom argumentu. Najjednostavnije rečeno, UPB se može definisati kao svako ponašanje koje je logički ostvarivo za sve ljude, u svakom trenutku. Ovo ne znači da se svi ljudi hoće ponašati moralno, već je preduslov da to samo bude logički moguće. Dodatno, UPB postulira da kad izostaje kapacitet za izbjegavanje, izostaje i mogućnost moralnog suđenja.

Pođimo od bazične inkluzivne pretpostavke da je bilo koji oblik segregacije nemoralan (Avramidis et al., 2010). Segregacija predstavlja čin prisilnog odvajanja. Ako je segregacija moralna, tj. UPB, to bi značilo da osoba koja je segregirana istovremeno mora da želi segregaciju (da bi bila UPB), ali i da je ne želi, da bi uopšte bila segregacija (a ne sporazumna asocijacija), što je logička kontradikcija i znači da segregacija ne može biti UPB. „Ne vrši segregaciju“, međutim, logički može ostvariti svako, u svakom trenutku. Dakle, tvrdnja o nemoralnosti (svake) segregacije je tačna, što uključuje i segregaciju na osnovu disabiliteta.

Međutim, u kompulzivnoj školi, regularnoj i specijalnoj, djeca su podijeljena u uzrasno segregirane razrede, iako sada i empirijski (Gray, 2013) i evolucionoistorijski (Zimbardo \& Duncan, 2012) znamo da su uzrasno homogene dječije grupe, naročito u odsustvu većeg broja odraslih osoba, izrazito neoptimalne i u 
socijalizacijskom i u razvojnom smislu. Prosto slijedeći raniji UPB-om validiran zaključak da je svaka segregacija nemoralna, nužno slijedi da je uzrasna segregacija takođe nemoralna, isto kao i segregacija na osnovu disabiliteta. Ovo inkluziju, koja propagira „uzrasnu prikladnost“ (npr. Neary \& Halvorsen, 1995) i operiše u modalitetu uzrasno stratifikovanih razreda, logički i samu čini oblikom segregacije. Čak i kada bi bilo tačno da inkluzija „manje segregira“ (vidjeti: Subotić, 2014), to je i dalje ne bi činilo moralno ispravnom, već samo eventualno manje nemoralnom od konvencionalnog specijalnog obrazovanja. Isto važi i za kontinuum uključivanja, nasuprot punoj inkluziji, među kojima, na osnovu prethodnog zaključka, takođe ne može postojati razlika sa aspekta apriorne moralnosti.

Demant apriorne moralnosti inkluzije moguće je izvršiti i na osnovu same prisilne prirode škole. Istorijski, škole kakve danas poznajemo, zasnovane su na polaznoj premisi o nužnosti slamanja dječijeg slobodnog duha i forsiranja pokoravanja autoritetima, isprva religijskim, a onda državnim (Gray, 2013). Od početka XIX vijeka, škola se eksplicitno shvata kao diseminator nacionalističkopolitičkih ideja i priprema za vojsku (Gray, 2013). Sve ove premise, uključujući i kompulzivnost, ostale su do danas suštinski nepromijenjene. Škola (i redovna i specijalna) je mjesto gdje su djeca primorana da budu mimo svoje volje, obavljaju nametnute zadatke i gdje su im brojne druge slobode takođe limitirane (Gray, 2013). Ova prisilna priroda školstva, u kojoj i inkluzija operiše, predstavlja očigledno kršenje UPB-a, jer da bi „prisili nekoga (da ide u školu)“ bilo UPB, osoba/učenik istovremeno to mora da želi (da bi bilo UPB) i ne želi (da bi bila riječ o kompulziji), što je logička kontradikcija. Dodatno, javne škole su trenutno finansirane putem prisilne realokacije resursa, što takođe narušava UPB (Molyneux, 2007). Kompulzivno obrazovanje, dakle, izvjesno nije apriorno moralno (Gray, 2013; Molyneux, 2007; Subotić, 2014), a samim tim ni vršenje inkluzije, kao ni izdvajanje u specijalne škole, ne mogu biti apriorno moralni činovi, pošto su zasnovani na prethodnoj prisili. To znači da je učenički kapacitet za izbjegavanje škole eliminisan, iz čega po UPB-u slijedi da čak i ako se učenicima (i roditeljima) omogući „izbor“ između inkluzije (pune ili parcijalne) i specijalne škole, riječ je o pseudo-izboru, koji se, prema ranije navedenom postulatu UPB-a, odigrava u okolnostima nemogućnosti moralnog suđenja. Prethodni zaključci zapravo dijelom objašnjavaju i kontinuirani pad kvaliteta obrazovanja na globalnom planu (Gray, 2013; Zimbardo \& Duncan, 2012), pošto je to logički očekivan ishod polazne apriorne nemoralnosti (Molyneux, 2007).

Postoji još nekoliko načina da se izvrši demant moralnosti inkluzije, koje sam detaljnije opisao na drugom mjestu (Subotić, 2014). Recimo, u slučaju pozivanja na pravo na obrazovanje, dok god postoji kompulzija, tj. ako to „pravo“ nije moguće odbiti, riječ je o povredi UPB-a. Neodrživ je i argument o kompulzivnoj školi kao ugovornoj obavezi koju roditelji prihvataju u ime svoje djece. Ako djeca još uvijek 
nemaju dovoljno razvijene kognitivne sposobnosti za dugoročno procesiranje posljedica svojih odluka i samim tim ne mogu ulaziti u ugovorne obaveze, onda očigledno nemaju ni mogućnost da se pridržavaju odrednica ugovorne obaveze, na koju bih ih roditelji samoinicijativno obavezali.

\section{Praktične implikacije}

Prethodne kritičke analize pokazuju da ključne postavke inkluzije (uključujući i moralne propozicije) nužno vode u logičke kontradikcije. To znači da sa $100 \%$ logičke sigurnosti možemo konstatovati da su ideje inkluzije filozofski nevalidne. Ovo ima više implikacija.

Prije svega, uprkos pokušajima (npr. Mišković, 2012), moguće je konstatovati da zbog logičke neutemeljenosti nikada neće postojati prediktivna teorija inkluzivnog obrazovanja (po aktuelnom shvatanju). Inkluzivna pozicija je ideološka (Kavale \& Forness, 2000; Kavale \& Mostert, 2003). Na osnovu ovoga je moguće predvidjeti izvjesnu eskalaciju praktičnih implementacionih problema, jer inkluzija, kao logički neutemeljen sistem, zapravo kauzalno pogoduje javljanju ili amplifikaciji seta problema, koji su do sada bili pogrešno identifikovani kao tehničke poteškoće implementacije (moralno) ispravne ideje, a ne kao problemi inherentni samoj pogrešnoj polaznoj osnovi. Odnosno, problemi nisu isključivi rezultat odbijanja da se prihvati „ispravna ideja inkluzije“, već su funkcija njene logičke, a konsekventno i empirijske nemogućnosti. Samim tim, inkluzija donekle odmaže upravo onima kojima pretenduje da pomaže, jer se neutemeljeno ustoličila kao „konačno rješenje“, iako to evidentno nije, kao što to nije ni sama kompulzivna obrazovna paradigma. Ako vjerujemo da imamo odgovor, prestajemo postavljati teška pitanja i ispitivati alternativne opcije. Pravo rješenje obrazovnih problema moguće je ostvariti tek nakon korjenite promjene polazne filozofije, što prije svega uključuje eliminaciju kompulzije, što se, iz sociopolitičkih razloga, realistično neće dogoditi ubrzo. U međuvremenu, ostaje set praktičnih problema koje ne možemo riješiti, ali ih možda možemo umanjiti. I upravo to je direktna implikacija ovog rada - sa empirijske tačke gledišta, trenutno se samo možemo baviti umanjivanjem nastale i rastuće štete. Nažalost, većina istraživanja inkluzije ne zasniva se na tom pristupu, već eksplicitno uzima ispravnost postavki inkluzije kao nužnu polaznu osnovu. Ovo takva istraživanja izvjesno čini praktično beskorisnim.

\section{Primjer ispitivanja stavova o inkluziji}

Tipičan primjer trivijalnih istraživanja inkluzije bila bi frekventna (Avramidis \& Norwich, 2002; Begeny \& Martens, 2007; Subotić, 2010, 2014) ispitivanja generičkih (obično nastavničkih) stavova o njoj. Begeny i Martens (Begeny \& 
Martens, 2007) sugerišu da takav istraživački fokus ne koristi učenicima, pošto se promjene u stavovima ne mogu koristiti kao pokazatelji validnosti ideje ili efikasnosti inkluzivnih programa. Vjerovatna motivacija za ovakva istraživanja iz pozicije inkluzionista jeste „pridobijanje onih koji ne vjeruju“, podrazumijevajući da uspješna implementacije inkluzije u velikoj mjeri zavisi od pozitivnog stava nastavnika (Avramidis \& Norwich, 2002), iako ne postoje potvrde da je riječ o relevantnom preduslovu - ovo možda jeste moguće, ali ni sam mehanizam, ni njegove implikacije nikada nisu uvjerljivo demonstrirani (Subotić, 2014). Važniji su stavovi prema konkretnim učenicima, jer su u vezi sa kvalitetom nastavne interakcije (Cook, Tankersley, Cook, \& Landrum, 2000), ali je ovo pitanje uglavnom empirijski zanemareno. Ako, pak, pođemo od pristupa umanjivanja štete, čak je i generičke stavove o inkluziji moguće smjestiti u potencijalno koristan kontekst. Konkretno, umjesto da stavove posmatramo kao sredstvo za pridobijanje podrške inkluzije, korisnije bi bilo tretirati ih, recimo, kao mjeru toga do koje granice je moguće ići, prije nego što problemi postanu nepodnošljivi. Postulirajući da je rad u inkluziji iz očiglednih razloga težak za same nastavnike, započeo sam seriju pionirskih istraživanja na teritoriji Republike Srpske (Subotić, 2010, 2011, 2014), sa svrhom provjere hipoteze da nastavnički stavovi o inkluziji ipak mogu biti konstrukt od koristi, tj. da mogu imati prediktivnu vrijednost za nastavnički distres. Iako je do tada bila podržana samo ograničenim brojem empirijskih nalaza iz inostranstva (Talmor, Reiter, \& Feigin, 2005), ova pretpostavka je potvrđena. Konkretno, nastavnički doživljaj prihvaćenosti $i$ prilagođenosti učenika s disabilitetima u inkluziji, pokazao se protektivnim za izgaranje na radu (Subotić, 2010), sa snažnijim intenzitetom efekta u odnosu na neuroticizam. Dobijene su i naznake negativne povezanosti ovog stava sa psihosomatskim pritužbama (Subotić, 2011). U kasnijem istraživanju (Subotić, 2014) formirao sam obuhvatniji prediktivni model. Potvrđeno je da niža prihvaćenost i prilagođenost učenika s disabilitetima predviđa više nastavničko izgaranje, ali da povjerenje u vlastitu vještinu ocjenjivanja (koje negativno korelira sa izgaranjem) moderatorski umanjuje tu vezu. Psihosomatske pritužbe takođe su moderirale ovu relaciju, ali amplifikatorski, iako nije replicirana njihova ranije utvrđena veza sa prihvaćenošću i prilagođenošću. S obzirom na statistički visoku prediktivnu snagu modela (29\% objašnjene varijanse izgaranja) i lakoću mjerenja ovih varijabli, umjesno je pretpostaviti da ovaj pristup predstavlja obećavajuću polaznu osnovu za uobličavanje procedure rane predikcije i prevencije nastavničkog izgaranja na radu u inkluziji. Na ovaj način, čak i ako ih nije moguće ukloniti, vjerovatno je moguće umanjiti ove probleme. To što ovakva pitanja nisu dovoljno razmatrana u „inkluzija je ispravna“ paradigmi, ilustruje praktične manjkavosti postojećih istraživanja, ali i pokazuje što je moguće uraditi kada prihvatimo da je ideja problematična, ali da smo trenutno primorani s njom da se nosimo najbolje što možemo. 
Iako sugerišem da je poželjno, nije čak ni neophodno eksplicitno/potpuno uvažiti logičku neodrživost inkluzije prilikom ispitivanja stavova o njoj, dok god postoji fokus na rješavanje konkretnih, praktičnih problema. Primjer kod nas bilo bi npr. istraživanje Jablan i saradnika (2011), koje iako polazi od pro-inkluzivne pozicije, problematici stavova pristupa pragmatički, pokazujući da iskustvo i obučenost nastavnika u radu sa djecom oštećenog vida ostvaruje nezavisne doprinose na različite nastavničke procjene aspekata rada u inkluziji, što ima direktne implikacije za način obuke nastavnika. Međutim, i kod nas je mnogo više istraživanja koja stavovima pristupaju iz pozicije obezbjeđivanja podrške ideji inkluzije (npr. Macura-Milovanović i Vujisić-Živković, 2011; Sindik, 2013), što očigledno znači manju aplikabilnost.

\section{Primjer ispitivanja socijalizacije i kategorizacije}

Iako inkluzionisti snažno propagiraju socijalizacijsko-razvojne benefite inkluzije za učenike s disabilitetima (npr. Wang, 2009), socijalna dinamika koju ovi učenici ostvaruju s vršnjacima uglavnom zahtijeva kontinuiranu facilitaciju (Terpstra \& Tamura, 2008) i rezultuje mješovitim ishodima (Lindsay, 2007; Salend \& Duhaney, 1999). Već sam naveo da je aktuelna koncepcija škole inherentno socijalizacijski i razvojno neoptimalna, čaki za učenike bez disabiliteta (Gray, 2013; Zimbardo \& Duncan, 2012), što su pitanja koja inkluzionisti sasvim ignorišu. Umjesto toga, inkluzivna učionica (Brice \& Miller, 2000) i inkluzija u cjelini (Wang, 2009) uglavnom bivaju opisani kao svojevrstan paragon socijalizacije, pri čemu se posebno naglašava da, za razliku od specijalnih škola (Hornby, 2012), u inkluzivnoj učionici djeca s disabilitetima nisu stigmatizirana imenovanjem (Brice \& Miller, 2000; Hornby, 2012).

U vezi sa ovim javlja se praktična dilema. Ako budu identifikovana, djeca s disabilitetima su možda pod rizikom za stigmatizaciju, ali ako ne budu identifikovana, postoji rizik da ne dobiju svu pažnju i instrukcije koje su im neophodne (Hornby, 2012). Ali, kako Hornby (2012) dalje sugeriše, ovo je lažna dilema, pošto takvi učenici nerijetko dobijaju „etikete“ od druge djece, pa i nastavnika, čak i kad nisu formalno identifikovani. Stigmatizacija nije nužno rezultat identifikacije, već činjenice da sami disabiliteti izdvajaju ovu djecu kao drugačiju na neki način. Ako bismo pošli od pozicije (pune) inkluzije, ovo objašnjenje bi bilo odbačeno, a manifestacije pripisane npr. nesposobnosti identifikacije sa onima koji su drugačiji (Brantlinger, 1997).

Ali, ako uvažimo da disabiliteti nisu samo subjektivne konstrukcije i da je kompulzivno školstvo generalno problematično (Gray, 2013; Molyneux, 2007; Zimbardo \& Duncan, 2012), slijedi da nije realistično moguće zadovoljiti individualne obrazovne potrebe učenika, imali oni disabilitete ili ne. Zapravo, moguće je iznijeti predikciju da će (posebno u obrazovnim sistemima ekonomski 
manje razvijenih zemalja), učenici s disabilitetima biti pod naročitim rizikom za zanemarivanje kada njihova formalna identifikacija nije učinjena. Empirijski nalazi iz Republike Srpske pružaju određene potvrde ovoj hipotezi. Konkretno (Subotić, 2014), učenici s kategorizacijom generalno bivaju manje socijalizacijski prihvaćeni i više odbačeni od strane drugih učenika (sa uglavnom umjerenim intenzitetima statističkih efekata). Međutim, učenici koji nisu kategorisani iz bilo kog razloga, ali za njih postoje indicije disabiliteta („preporuka za kategorizaciju“), prolaze čak i neznatno gore od kategorisanih učenika. Mogući razlozi za ovo su vjerovatno tehničko-finansijske prirode (Subotić, 2014), jer inkluzija zahtijeva velika ulaganja, obuku i podršku, što u Republici Srpskoj nije slučaj; specijalni edukatori nisu dio inkluzivne reforme, odjeljenja su često prekrcata, a plan i program preobiman i neprilagođen. U takvim okolnostima, nema dovoljno uslova za neophodnu facilitaciju socijalizacije učenika s disabilitetima, instrukciona pažnja koja im se može pokloniti je ograničena, a ako pri tome nisu kategorisani, formalno su na nižoj poziciji po „listi prioriteta“ u odnosu na kategorisane učenike. Čini se umjesnim pretpostaviti da je situacija vjerovatno slična i u okruženju (npr. Srbija).

Ovakva situacija je zabrinjavajuća i empirijski ilustruje šta se događa kada se logički inkonzistentna ideja pokuša operacionalizovati u uslovima nedovoljne podrške za ispomoć u očekivanim problemima. Istovremeno, pokazuje i kako princip neimenovanja može djelovati kontraproduktivno po one koji nisu imenovani. To ne implicira kauzalitet, niti znači da bi masovnija dodjela kategorizacija bila preferabilna, ali ukazuje na to da je u uslovima niske podrške, u kojima obrazovanje u mnogim zemljama u regionu egzistira, iluzorno očekivanje o maksimizaciji obrazovnih benefita u inkluziji (Brice \& Miller, 2000) neophodno zamijeniti setom empirijskih pitanja sa eksplicitnom svrhom umanjenja štete koja se u realnim okolnostima javlja. Ovo je smijer istraživanja koji tek treba da dobije ekspanziju.

\section{Zaljučci i preporuke}

I inkluzija i specijalne škole manifestacije su šireg problema aktuelnog obrazovanja koje samo po sebi nije ni moralno (Gray, 2013; Molyneux, 2007), niti je biološki ili empirijski opravdano (Gray, 2013; Zimbardo \& Duncan, 2012). Ovo je civilizacijski problem sa kojim se tek trebamo uhvatiti u koštac. Polazeći od utemeljene i humane pozicije da je svaki oblik segregacije nemoralan (Avramidis et al., 2010), inkluzija je pokušala da izvrši veliku reformu obrazovanja, ali zbog nesposobnosti da uvidi širi kontekst problema, nije ispoštovala sopstveni princip i kao rješenje za segregaciju ponudila je - drugačiju segregaciju. Umjesto da riješi problem, indukovala je set drugačijih problema, a diskurs odvukla u ideološke (Kavale \& Forness, 2000) i fundamentalno irelevantne debate (npr. nemoralnost 
specijalnog obrazovanja). Dugoročno rješenje za sve ovo je filozofske, a tek nakon toga empirijske prirode.

Ipak, u međuvremenu, ostaje set praktičnih pitanja, koja su, iako izvjesno prelaznog karaktera, itekako vrijedna razmatranja. Ovo je naročito naglašeno u malim i finansijski nedovoljno razvijenim zemljama, čiji obrazovni sistemi ne mogu priuštiti ulaganja neophodna za maskiranje progresivno rastućih problema.

U okviru aktuelne obrazovne paradigme te probleme ne možemo riješiti, ali neznatnom promjenom ugla gledanja i ostavljanjem retorike po strani, možemo ih umanjiti i eventualno držati pod kontrolom. Pored već postojećih istraživanja koja se bave praktičnim pitanjima dijagnostike i tretmana disabiliteta (vidjeti npr. Gligorović, 2012), koja su korisna, ali nisu dovoljna, potrebno je, kao što sam ilustrovao na primjeru sopstvenih istraživanja, ući u škole i učionice, identifikovati krajnje praktična pitanja i pokušati na njih odgovoriti, sa svrhom umanjenja problema, dok ne pronađemo valjana dugoročna rješenja. Ni inkluzija, ni konvencionalno specijalno obrazovanje, kao ni kompulzivna obrazovna paradigma u cjelini - to izvjesno nisu.

\section{Reference}

Avramidis, E., \& Norwich, B. (2002). Teachers' attitudes towards integration/ inclusion: A review of the literature. European Journal of Special Needs Education, 17(2), 129-147.

Avramidis, E., Bayliss, P., \& Burden, R. (2010). A survey into mainstream teachers' attitudes towards the inclusion of children with special educational needs in the ordinary school in one local education authority. Educational Psychology, 20(2), 191-211.

Begeny, J. C., \& Martens, B. K. (2007). Inclusionary education in Italy: A literature review and call for more empirical research. Remedial and Special Education, 28, 80-94.

Brantlinger, E. (1997). Using ideology: Cases of nonrecognition of the politics of research and practice in special education. Review of Educational Research, 67(4), 425-459.

Brice, A., \& Miller, R. J. (2000). Case studies in inclusion: What works, what doesn't. Communication Disorders Quarterly, 21(4), 237-241.

Cook, B. G., Semmel, M. I., \& Gerber, M. M. (1999). Attitudes of principals and special education teachers toward the inclusion of students with mild disabilities: Critical differences of opinion. Remedial and Special Education, 20(4), 199-207.

Cook, B. G., Tankersley, M., Cook, L., \& Landrum, T. J. (2000). Teachers' attitudes toward their included students with disabilities. The Council for Exceptional Childern, 67(1), 115-135. 
Fuchs, D., \& Fuchs, L. S. (2000). Inclusion versus full inclusion. In W. L. Heward (Ed.), Exceptional children: An introduction to special education (6th ed.) (pp. 80-81). Englewood Cliffs, NJ: Prentice Hall/Merrill.

Gallagher, D. J. (2001). Neutrality as a moral standpoint, conceptual confusion and the full inclusion debate. Disability \& Society, 16(5), 637-654.

Gligorović, M. (Ur.). (2012). II naučni skup: Stremljenja i novine u specijalnoj edukaciji i rehabilitaciji [Zbornik radova]. Beograd, Srbija: Univerzitet u Beogradu, Fakultet za specijalnu edukaciju i rehabilitaciju.

Gray, P. (2013). Free to learn. New York, NY: Basic Books.

Hornby, G. (2012). Inclusive education for children with special educational needs: A critique of policy and practice in New Zealand. Journal of International and Comparative Education, 1(1), 52-60.

Jablan, B., Jolić-Marjanović, Z. i Grbović, A. (2011). Uticaj iskustva i obučenosti nastavnika na njihove stavove prema obrazovanju dece sa oštećenjem vida u srednjim školama. Zbornik instituta za pedagoška istraživanja, 43(1), 122-138.

Kauffman, J. M. (1999). Commentary: Today's special education and its messages for tomorrow. The Journal of Special Education, 32(4), 244-254.

Kavale, K. A., \& Forness, S. R. (2000). History, rhetoric, and reality: Analysis of the inclusion debate. Remedial and Special Education, 21(5), 279-296.

Kavale, K. A., \& Mostert, M. P. (2003). River of ideology, islands of evidence. Exceptionality, 11(4), 191-208.

Lindsay, G. (2007). Annual review: Educational psychology and the effectiveness of inclusive education/mainstreaming. British Journal of Educational Psychology, 77, 1-24.

Lipsky, D. K., \& Gartner, A. (1991). Restructuring for quality. In J. W. Lloyd, A. C. Repp, \& N. N. Singh (Eds.), The regular education initiative: Alternative perspectives on concepts, issues, and models (pp. 43-56). Sycamore, IL: Sycamore Publishing.

Macura-Milovanović, S. i Vujisić-Živković, N. (2011). Stavovi budućih učitelja prema inkluziji: Implikacije za inicijalno profesionalno obrazovanje. Pedagogija, 4(11), 633-647.

Mamlin, N., \& Harris, K. R. (1998). Elementary teachers' referral to special education in light of inclusion and prereferral: "Every child is here to learn... but some of these children are in real trouble". Journal of Educational Psychology, 90(3), 385-396.

Mišković, M. M. (2012). Sociološki kontekst inkluzivnog obrazovanja (I). Pedagoška stvarnost, 58(3), 500-511.

Molyneux, S. (2005, November 29). The argument from morality or, how we will win... [Web log comment]. Retrieved from http://goo.gl/oXc68L

Molyneux, S. (2007). Universally preferable behaviour: A rational proof of secular ethics. USA: The Freedomain Library. 
Neary, T., \& Halvorsen, A. (1995). What is “Inclusion"? ERIC Digest, ED. 393248.

Popper, K. (2005). The logic of scientific discovery. London \& New York: Taylor \& Francis e-Library. (Original paper published in 1935).

Salend, S. J., \& Duhaney, L. M. G. (1999). The impact of inclusion on students with and without disabilities and their educators. Remedial and Special Education, 20(2), 114-126.

Sindik, J. (2013). Konstrukcija upitnika stavova odgojiteljica prema inkluziji djece s teškoćama u razvoju u dječje vrtiće. Specijalna edukacija i rehabilitacija, 12(3), 309-334.

Sokal, A. (2006). Pseudoscience and postmodernism: Antagonists or fellowtravelers? In G. G. Fagan (Ed.), Archaeological fantasies: How pseudoarchaeology misrepresents the past and misleads the public (pp. 286-361). London \& New York: Routledge.

Cohon, R. (2010). Hume's Moral Philosophy. In E. N. Zalta, The Stanford Encyclopedia of Philosophy (Fall 2010 ed.). Retrieved from http://goo.gl/ yNdNzv

Subotić, S. (2010). Struktura stavova o inkluziji i sindrom izgaranja na poslu kod prosvjetnih radnika u Republici Srpskoj: Pilot studija. Primenjena psihologija, 3(2), 155-174.

Subotić, S. (2011). Rad u inkluzivnoj nastavi i psihosomatske manifestacije kod nastavnika različitih usmjerenja. Rad prezentovan na konferenciji Individualizacija vaspitno-obrazovnog rada u inkluzivnim uslovima, Beograd, Srbija.

Subotić, S. (2014). Evaluacija inkluzivne obrazovne reforme u osnovnoj školi. (Neobjavljena doktorska disertacija). Filozofski fakultet, Univerzitet u Novom Sadu, Novi Sad, Srbija.

Talmor, R., Reiter, S., \& Feigin, N. (2005). Factors relating to regular education teacher burnout in inclusive education. European Journal of Special Needs Education, 20(2), 215-229.

Terpstra, J. E., \& Tamura, R. (2008). Effective social interaction strategies for inclusive settings. Early Childhood Education Journal, 35, 405-411.

Thomas, G., \& Glenny, G. (2002). Thinking about inclusion. Whose reason? What evidence? International Journal of Inclusive Education, 6(4), 191-208.

Uduigwomen, A. (2005). Philosophical objections to the knowability of truth: Answering postmodernis. Quodlibet Journal, 7(2). Retrieved from http://goo. $\mathrm{gl} / \mathrm{B} 2 \mathrm{oMLF}$

Wang, H. L. (2009). Should all students with special educational needs (SEN) be included in mainstream education provision? - A critical analysis. International Education Studies, 2(4), 154-161.

Zimbardo, P. G., \& Duncan, N. S. (2012).The demise of guys: Why boys are struggling and what we can do about it. New York: TED ebooks. 
Žiljak, O. (2013). Ishodi učenja i inkluzivna edukacija učenika s intelektualnim teškoćama. Revija za socijalnu politiku, 20(3), 275-291. 


\section{Siniša Subotić}

NGO "Persona", Banjaluka; CEON, Belgrade

\section{INCLUSION, MORALITY AND REALITY: THE ANSWERS TO TOUGH QUESTIONS}

\begin{abstract}
Inclusion in education is rapidly becoming the dominant paradigm for educating the children with disabilities, despite generally inconclusive research findings regarding the formal outcomes of its implementation. This review gives the systematic logical and philosophical deconstruction of the key ideas of inclusion (such as the postmodern rejection of the scientific method and the denial of the existence of disabilities), while pointing out to their apparent logical contradictions. Special attention was given to the formal debunking of postulated a priori moral correctness of inclusion. Relying on the moral theory of the universally preferable behavior, it was shown that the inclusion, given that it is based on a compulsive educational paradigm and agesegregation, is a priori equally morally unjustifiable as the special education is. Although it correctly proposed the immorality of segregation of any kind, inclusion logically also turned out to be a form of segregation. This has important practical implications, because it shows that the inclusion itself causes many problems which are wrongly attributed to its inadequate implementation, and that its optimal implementation is not really possible. This partly explains the inherent trivialness and a lack of practical usefulness of many studies dealing with inclusion, such as the studies of attitudes. The practical examples were given, showing how it is possible to overcome the problem of triviality and how to answer empirical questions of immediate relevance. In addition, it was pointed out that these issues, although important, are of a transitional nature, because the apparent conclusion is that the problem of the education of children with or without disabilities cannot be solved within the current educational paradigm, but in the meantime, we are forced to deal with the "minimization of harm".
\end{abstract}

Keywords: inclusion, morality, the universally preferable behavior (UPB), forced education, research review 